\title{
The Relationship Between Take-up of Prescription Drug Subsidies and Medicaid Among Low-Income Medicare Beneficiaries
}

J Gen Intern Med 36(9):2873-6

DOI: $10.1007 / \mathrm{s} 11606-020-06241-y$

(c) Society of General Internal Medicine 2020

\section{INTRODUCTION}

Medicare premiums and cost-sharing can pose a substantial financial burden on beneficiaries, half of whom have incomes below $\$ 26,200 .^{1}$ Beneficiaries with low incomes and assets may qualify for assistance with these costs through full Medicaid, the Medicare Savings Programs (MSPs, which are limited Medicaid benefits), and the Part D Low-Income Subsidy (LIS). ${ }^{2,3}$ However, a substantial proportion of individuals who qualify for these programs are not enrolled. ${ }^{3-5}$

These programs are linked in ways that may be unknown to Medicare beneficiaries. All beneficiaries who are eligible for full or limited Medicaid qualify for the LIS, which eliminates premiums and lowers cost-sharing in the Medicare Part D program. Moreover, beneficiaries who receive Medicaid are automatically enrolled in the LIS. Because auto-enrollment is the main pathway into the LIS, ${ }^{2}$ there is concern that low take-up of Medicaid could contribute to low LIS take-up. Foregoing the LIS may have adverse consequences for patients: CMS has estimated that this program reduces average annual outof-pocket prescription drug spending by $\$ 4000$ and receiving the LIS has been linked to improved medication adherence. ${ }^{3,6}$

In this study, we examined take-up of the LIS and Medicaid among Medicare beneficiaries who qualified for both programs. We go beyond prior analyses that report average enrollment by program by examining whether LIS take-up mirrors Medicaid enrollment at income levels where individuals qualify for limited Medicaid benefits that have low take-up rates, ${ }^{5}$ highlighting opportunities for policy reforms to increase participation in both programs.

\section{METHODS}

We analyzed Medicare beneficiaries in the 2008-16 waves of the Health and Retirement Study (surveyed biennially) and linked administrative indicators of Medicaid and LIS enrollment. We restricted our sample to financial respondents (i.e., individuals most knowledgeable about a household's finances) who qualified for Medicaid and the LIS based on their income and assets.

In primary analyses, we examined LIS and Medicaid take-up as a function of income relative to the federal eligibility threshold for the Qualified Medicare Beneficiary MSP ( $100 \%$ of FPL). Beneficiaries whose income is below this threshold qualify for assistance with outof-pocket costs in Medicare Parts A and B (provided they have low assets) while those with incomes of 101$135 \%$ of FPL only qualify for Medicaid assistance with the Part B premium. In secondary analyses, we assessed take-up above and below state-specific income eligibility thresholds for full Medicaid. Finally, we estimated adjusted differences in LIS take-up above and below these thresholds, controlling for beneficiaries' demographic and socioeconomic characteristics, health status, disability, Medicare Advantage enrollment, and state and year fixed effects. We adjusted for survey weights to produce estimates that are nationally representative of the community-dwelling Medicare population.

\section{RESULTS}

LIS-eligible Medicare beneficiaries qualify for different Medicaid benefits depending on their income and assets

Received May 19, 2020

Accepted September 11, 2020

Published online September 21, 2020 
Table 1 Characteristics of Medicaid and Part D Low-Income Subsidies Available to Low-Income Medicare Beneficiaries

\begin{tabular}{|c|c|c|c|c|c|}
\hline \multirow[b]{2}{*}{ Program } & \multirow[b]{2}{*}{ Full Medicaid* } & \multicolumn{3}{|c|}{ Limited Medicaid (Medicare Savings Programs) } & \multirow[b]{2}{*}{$\begin{array}{l}\text { Full Part D Low- } \\
\text { Income Subsidy } \\
\text { (LIS) }^{\dagger}\end{array}$} \\
\hline & & $\begin{array}{l}\text { Qualified Medicare } \\
\text { Beneficiary program }\end{array}$ & $\begin{array}{l}\text { Specified Low- } \\
\text { Income Medicare } \\
\text { Beneficiary } \\
\text { program }\end{array}$ & $\begin{array}{l}\text { Qualifying } \\
\text { Individual } \\
\text { program }\end{array}$ & \\
\hline Benefits provided & $\begin{array}{l}\text { Pays for Medicare Part A and B } \\
\text { premiums and cost-sharing } \\
\text { Covers additional services such } \\
\text { as long-term nursing home care }\end{array}$ & $\begin{array}{l}\text { Pays for Medicare } \\
\text { Part A and B } \\
\text { premiums and cost- } \\
\text { sharing }\end{array}$ & $\begin{array}{l}\text { Pays for the } \\
\text { Medicare Part B } \\
\text { premium }\end{array}$ & $\begin{array}{l}\text { Pays for the } \\
\text { Medicare Part B } \\
\text { premium }\end{array}$ & $\begin{array}{l}\text { Pays for premiums } \\
\text { in qualifying Part D } \\
\text { plans } \\
\text { No Part D } \\
\text { deductible } \\
\text { Nominal Rx } \\
\text { copayments, with } \\
\text { annual } \\
\text { out-of-pocket limit }\end{array}$ \\
\hline $\begin{array}{l}\text { Income eligibility } \\
\text { threshold }\end{array}$ & $\begin{array}{l}\text { Varies by state, range: } \\
63-100 \% \text { of FPL }\end{array}$ & $\begin{array}{l}100 \% \text { of FPL except } \\
\text { in } 4 \text { states }^{\S}\end{array}$ & $\begin{array}{l}120 \% \text { of FPL except } \\
\text { in } 4 \text { states }^{\S}\end{array}$ & $\begin{array}{l}135 \% \text { of FPL } \\
\text { except in } 4 \text { states }\end{array}$ & $135 \%$ of FPL \\
\hline $\begin{array}{l}\text { Asset eligibility } \\
\text { threshold (as of } \\
2020 \text { ) }\end{array}$ & $\begin{array}{l}\text { Varies by state, range: } \\
\$ 1500-\$ 7860 \text { for individuals, } \\
\$ 1500-\$ 11,800 \text { for couples } \\
\text { (AZ waives asset test) }\end{array}$ & \multicolumn{3}{|c|}{$\begin{array}{l}\text { Varies by state, range: } \$ 7860-\$ 50,000 \text { for individuals, } \\
\$ 11,800-\$ 75,000 \text { for couples ( } 9 \text { states waive asset test) }\end{array}$} & $\begin{array}{l}\$ 7860 \text { for } \\
\text { individuals, } \\
\$ 11,800 \text { for couples }\end{array}$ \\
\hline $\begin{array}{l}\text { Administration and } \\
\text { funding }\end{array}$ & $\begin{array}{l}\text { Administered by states with } \\
\text { state and federal funding }\end{array}$ & $\begin{array}{l}\text { Administered by } \\
\text { states with state and } \\
\text { federal funding }\end{array}$ & $\begin{array}{l}\text { Administered by } \\
\text { states with state and } \\
\text { federal funding }\end{array}$ & $\begin{array}{l}\text { Federal block } \\
\text { grant administered } \\
\text { by states }\end{array}$ & $\begin{array}{l}\text { Federally } \\
\text { administered and } \\
\text { funded }\end{array}$ \\
\hline
\end{tabular}

*Medicaid eligibility criteria for aged, blind, or disabled individuals

†Medicare beneficiaries who qualify for full or limited Medicaid are eligible for full LIS. We did not examine "partial" LIS, a reduced subsidy available to Medicare beneficiaries with incomes of 136-150\% of FPL who also meet asset limits

$\$$ As of 2018, 22 states followed income eligibility limits from the Supplemental Security Income program (approximately $75 \%$ of FPL) and 17 states extended Medicaid eligibility to $100 \%$ of FPL

${ }^{\S}$ States disregarding additional income to increase MSP eligibility above federal levels: Connecticut (as of 2010), District of Columbia (as of 2006), Indiana (2014), and Maine (as of 2007)

(Table 1). Consistent with prior research, ${ }^{5}$ we found lower Medicaid take-up among beneficiaries who qualified for more limited Medicaid benefits based on income. LIS take-up closely tracked Medicaid enrollment as a function of income and was lowest among beneficiaries with incomes of 101-135\% of FPL (Fig. 1). In regression analyses, we estimated that LIS take-up was 24.0 percentage points lower $(P<0.001)$ among beneficiaries whose income exceeded the eligibility threshold for the Qualified Medicare Beneficiary MSP and 13.7 percentage points lower $(P=0.001)$ among those whose income exceeded state eligibility thresholds for full Medicaid.

\section{DISCUSSION}

Among LIS-eligible Medicare beneficiaries, we observed markedly lower LIS enrollment - corresponding to lower Medicaid take-up — among individuals who qualify for limited
Medicaid benefits based on their income. Because Medicaid enrollees automatically receive the LIS, our findings suggest that low enrollment in limited Medicaid contributes to low take-up of the LIS.

Our findings underscore Medicaid's importance in facilitating take-up of the LIS. Prior research linked low MSP enrollment to limited program awareness and the complexity of applying for these benefits. ${ }^{2}$ To broaden MSP and LIS participation, states could consider simplifying or automating MSP enrollment, such as waiving asset tests or presumptively enrolling recipients of other means-tested assistance (e.g., food stamps and home heating assistance) in MSPs that cover the Part B premium. Such policies would come at a modest cost to states (in 2020 , the Part B premium was $\$ 144.60 /$ month) and could be partially offset by savings to State Pharmaceutical Assistance Programs to the extent lowincome Medicare beneficiaries use these programs in lieu of the federally funded LIS. ${ }^{2}$ 


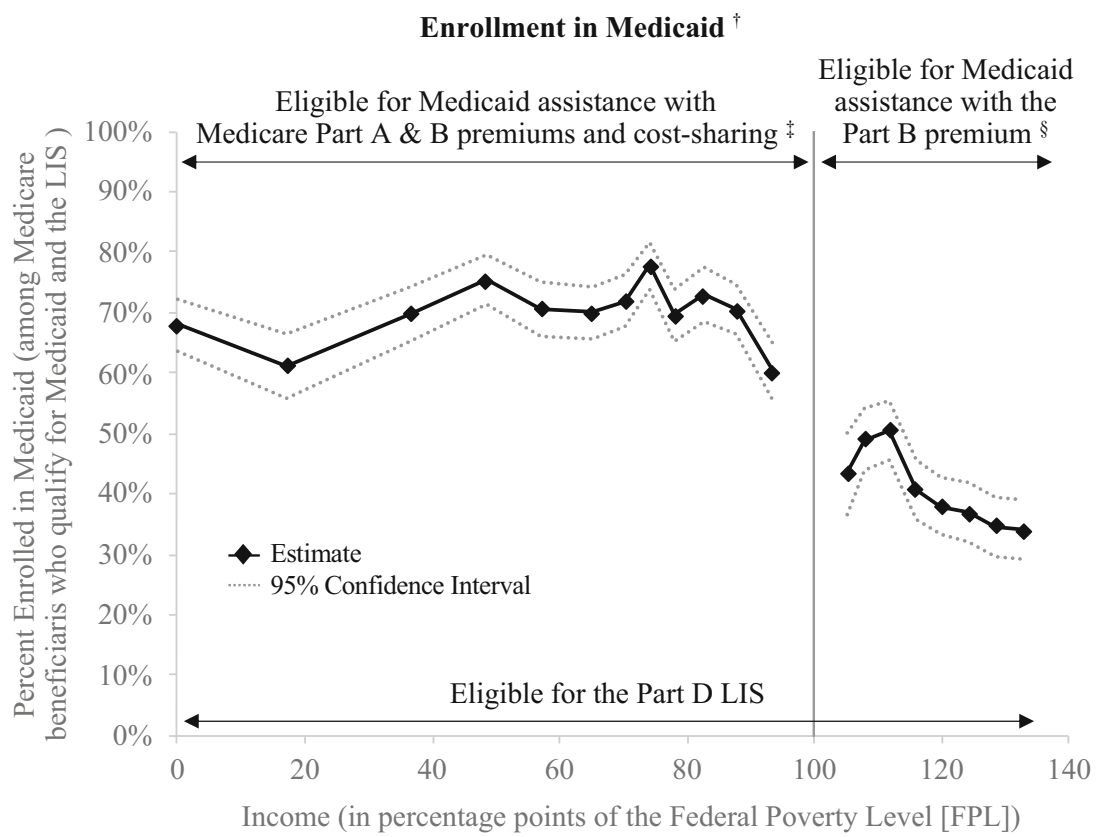

Enrollment in the LIS $\|$

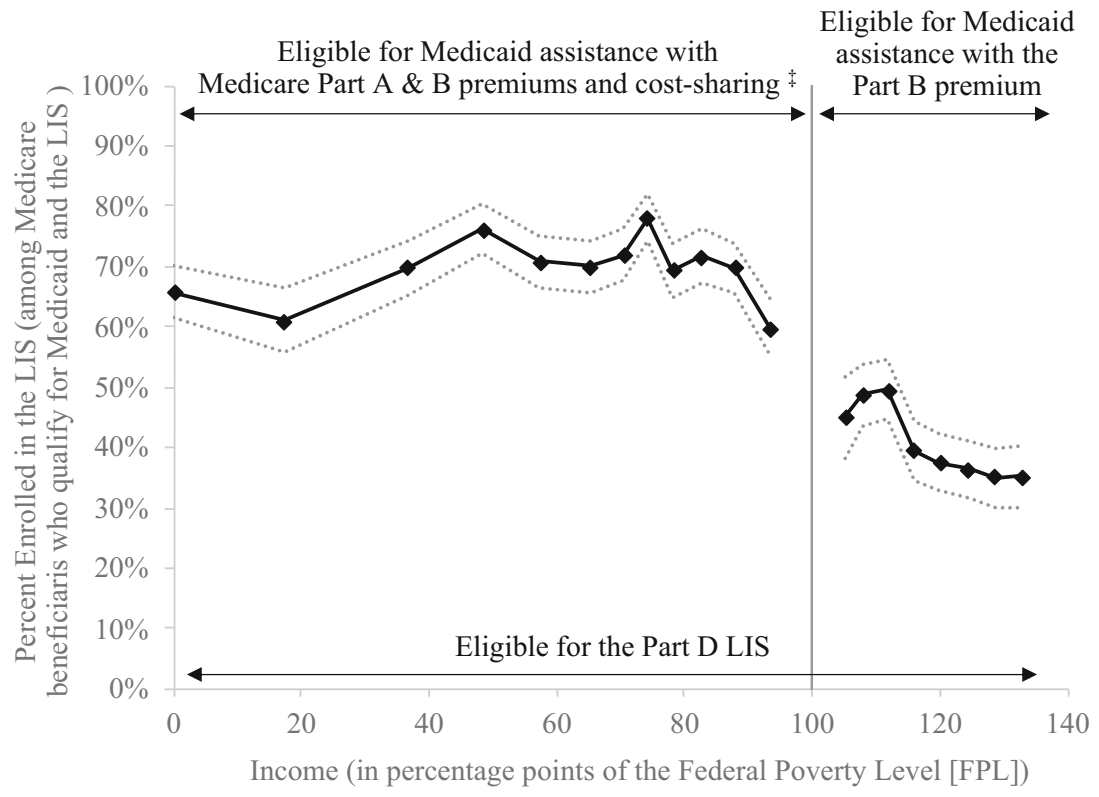

Figure. 1 Enrollment in Medicaid and the LIS by income. Graphs display proportion of Medicare beneficiaries enrolled in full or partial Medicaid (top panel) and Part D LIS (bottom panel) by income relative to income eligibility threshold for the Qualified Medicare Beneficiary MSP (100\% of the Federal Poverty Level). Incomes within \pm 4 percentage points of this threshold were excluded. Observations grouped into 20 equally sized income bins; mean enrollment by program is plotted within each bin. Solid lines are estimates; dashed lines are 95\% confidence intervals. Medicare beneficiaries in biennial 2008-2016 waves of the Health and Retirement Study (HRS) linked to contemporaneous indicators of Medicaid and LIS enrollment from the Medicare Master Beneficiary Summary File. The study sample included HRS respondents who met eligibility criteria for Medicaid and LIS based on income and assets and excluded respondents in Connecticut, the District of Columbia, Maine, and Indiana (on or after 2014), as these states disregarded income to increase eligibility for the MSPs above the LIS income threshold. Study sample of 7897 HRS observations represented 29,113,139 person-years in community-dwelling Medicare population. ${ }^{\dagger}$ Individuals receiving full or limited Medicaid for $\geq 1$ month of study year identified from dual eligibility codes in Medicare Master Beneficiary Summary file. ${ }^{*}$ Assistance with out-of-pocket costs in Medicare Parts A and B provided via full Medicaid or Qualified Medicare Beneficiary MSP. Individuals must meet income and asset tests to qualify for these programs (Table 1). ${ }^{\S}$ Assistance with Medicare Part B premium provided by Specified Low-Income Medicare Beneficiary and Qualifying Individual MSPs. Individuals must meet income and asset tests to qualify (Table 1). "Individuals receiving full Part D Low-Income Subsidy (LIS) for $\geq 1$ month of study year identified from low-income cost share codes in Medicare Master Beneficiary Summary File. 
Eric T. Roberts, $P h D^{1}$

Alexandra Glynn, $B A^{1}$

Julie M. Donohue, $P \mathrm{PD}^{1}$

Lindsay M. Sabik, $\mathrm{PhD}^{1}$

${ }^{1}$ Department of Health Policy and Management, University of Pittsburgh Graduate School of Public Health, Pittsburgh, PA, USA

Corresponding Author: Eric T. Roberts, PhD; Department of Health Policy and Management, University of Pittsburgh Graduate School of Public Health Pittsburgh, PA, USA (e-mail: eric.roberts@pitt.edu).

Funding This work was supported by grants from the Agency for Healthcare Research and Quality (KO1HSO26727) and the University of Pittsburgh Pepper Older Americans Independence Center (subaward from National Institute on Aging grant P30 AG024827-13).

\section{Compliance with Ethical Standards:}

Disclaimer: This content is solely the responsibility of the authors and does not necessarily represent the official views of the Agency for Healthcare Research and Quality or the National Institutes of Health.
Conflict of Interest: The authors declare that they do not have a conflict of interest.

\section{REFERENCES}

1. Cubanski J, Neuman T, Damico A, Smith K. Medicare beneficiaries' outof-pocket health care spending as a share of income now and projections for the future. The Henry J. Kaiser Family Foundation. 2018.

2. Chapter 5: Increasing participation in the Medicare savings programs and the low-income drug subsidy. Report to the Congress: Medicare Payment Policy. Washington, DC: Medicare Payment Advisory Commission; 2008:307-28.

3. Summer L, Hoadley J, Hargrave E. The Medicare Part D low-income subsidy program: experience to date and policy issues for consideration: Henry J. Kaiser Family Foundation; 2010.

4. Pezzin LE, Kasper JD. Medicaid enrollment among elderly medicare beneficiaries: individual determinants, effects of state policy, and impact on service use. Health Serv Res 2002;37(4):827-47.

5. MACPAC. Medicare Savings Programs: New Estimates Continue to Show Many Eligible Individuals Not Enrolled. Washington, DC: Medicaid and CHIP Payment Advisory Commission; 2017.

6. Yala SM, Duru OK, Ettner SL, Turk N, Mangione CM, Brown AF. Patterns of prescription drug expenditures and medication adherence among medicare part D beneficiaries with and without the low-income supplement. BMC Health Serv Res 2014;14(1):665.

Publisher's Note: Springer Nature remains neutral with regard to jurisdictional claims in published maps and institutional affiliations. 